Print ISSN: 2052-6393(Print), Online ISSN: 2052-6407(Online)

\title{
INTEGRATED MANAGEMENT SYSTEM IMPLEMENTATION IN SMES: A PROPOSED MODEL FOR ORGANISATIONAL PERFORMANCE AND SUSTAINABILITY
}

\author{
Hesham Magd \\ Associate Dean for Quality Assurance and Accreditation, Faculty Head of Business and \\ Economics, Modern College of Business and Science, Muscat, Oman \\ Email: Hesham.Magd@mcbs.edu.om
}

\begin{abstract}
Henry Karyamsetty
Assistant Professor, Transportation, Logistics and Safety Management Department, Faculty of Business and Economics, Modern College of Business and Science, Muscat, Oman

Email: Henry.Karyamsetty@mcbs.edu.om
\end{abstract}

\begin{abstract}
Management systems are important for any organization especially to small and medium enterprises (SMEs) that face limitations in areas that larger firms have stability. One of the approaches to overcome these challenges and maintain business growth is implementing and following an integrated management system (IMS), as a model for improving the organizational performance and to maintain sustainable growth in a business. SMEs are global leaders in providing employment opportunities - around 60-70\% in developed economies and 99\% of all business in OECD countries, hence sustaining them and enhancing their performance in the business market over larger firms is critical to retain employment opportunities in the future. IMS provides internal and external benefits, especially being more feasible and appropriate for SMEs by increasing competitiveness, stability in business, effective resources management and resilience during market challenges. However, it's important to focus on the specific characteristics and factors that determine SMEs effective implementation of IMS. To overcome the various barriers limiting their business growth and organizational performance, the proposed conceptional model developed through this research study in conjunction with the associated factors would enable SMEs to effectively implement IMS to achieve organizational performance and sustainability. SMEs in order to maintain a competitive nature in the emerging business markets must adopt different strategies and mechanisms to address the challenges in technology and innovation, which are the prime impacting factors that define a clear road map for sustainable growth.
\end{abstract}

KEYWORDS: SMEs, management system, sustainability, organisation, integrated, performance.

\section{INTRODUCTION}

Globally, small and medium enterprises (SME) are gaining momentum predominantly in developing and underdeveloped countries, arising because of the large demand for workforce employment and the potential to boost global economic development through their value-added business(es) (Rotar et al., 2019). These firms are considered as SMEs dependent on the number of employees working, which changes from country to country. However, the European Union considers SMEs as businesses which have no more than 250 employees (www.oecd.org. 2019). 
While in USA the limit is no more than 500 employees Yang (2018). These enterprises are also viewed as significant avenues for economic growth and potential employment sectors among large companies by contributing to more than 50\% to the global GDP (www.ilo.org. 2019). Globally, $90 \%$ of the business population originates from SMEs, providing $60-70 \%$ of employment in developed economies, for example, SMEs account for 97.5\% Western Australia, and $98 \%$ in Taiwan, while European countries have a substantial percent of SMEs with $99 \%$ (Arnold, 2019; Yang, 2018). Statistics have revealed a decreasing trend of SMEs between 2008 and 2013, especially in OECD countries. While Germany, New Zealand and Brazil showed an increase in the size of SMEs, which caused a negative effect on the employment rates, economy, and productivity (www. oecd. org. 2017).

SMEs are perceived to constitute $99 \%$ of all the firms in OECD countries forming a major source of employment through manufacturing and service providing sectors, accounting for approximately 60-70\% of jobs (www.oecd.org. 2019). These enterprises are vital for the future as they assure a tremendous scope for job creation, boosting the economic development, innovation in market strategies as described by Hillary (2000). By the turn of 2030, analysis from the world bank indicates a necessity of 600 million jobs to meet the global employment workforce, which prioritizes developing small and mediums enterprises worldwide (www. Worldbank.org. 2020). Conversely, many of these enterprises have constraints and struggle within the competitive markets due to regulatory framework, limited access to finance and skill shortages, which is affecting their ability to sustain a business (www.oecd.org, 2019). On the contrary, globalization, technological upgrades, management system compliance procedures etc. also pose a bigger challenge to SMEs to compete with bigger companies that have wider reaching business connections and a larger supply chain network. Thus, to survive the competitive market and sustain themselves amongst the larger firms, SMEs have to focus on combating their challenges and the limitations they are facing by making proactive change via initiatives such as imbibing management systems into their business to get wider market access, effective recognition, reinforcing of customer confidence and meeting regulatory frameworks.

Research studies are being conducted by various researchers, few of them have studied the determining factors and indicators that influence the growth of SMEs with the current challenges in the business market (Olaru et al., 2014). All this work only points towards finding out the ways to make SMEs more sustainable in terms of meeting business challenges, competing with bigger firms, to tide over with business strategies. To overcome the changing scenario and trends, SMEs should be revolutionized by implementing regulatory framework, incorporating management systems into their process for successful business growth and continuity.

This paper describes the influence of management systems on SMEs by reviewing the different studies done by researchers. The study deals with the application of integrate management system(s) for sustaining the SMEs business in the market and sheds light on the influence of management system(s) on organizational performance in sustaining business continuity.

\section{TOTAL QUALITY MANAGEMENT SYSTEM AND SMES PERFORMANCE}

There is a growing emphasis on the importance of incorporating management systems in organizations to enhance the quality and production, more specifically in SMEs as they are potential sectors for boosting economic development by creating jobs in the following centuries. The success of any SMEs depends on its contribution to economic development by 
creating jobs, growth in business opportunities and its performance which are all directly influenced by quality management systems. Results from studies revealed that performance of SMEs are subsidized by total quality management systems in bringing high results and improvements to business production (Pinho, 2008). Furthermore, innovation strategies of organizations have a positive influence on their performance that comes from understanding the relationship between consumer orientation and innovation, though based on the survey data $30 \%$ to $60 \%$ of SMEs in OECD countries are considered innovative in broad sense (www.oecd. org 2019). Gotzamani et al., 2006 (as cited in Singh, 2011, pp. 7-10) has identified 11 key enabling factors from his analysis that impacts on the success of total quality management system in SMEs and established a framework for improving the performance and customer satisfaction, in conjunction with Pambreni et al. (2019) who concluded customer focus, continuous improvement, total employee involvement. Strategically based together, these are influencing factors for organization performance up to $40 \%$ while the rest are impacted by other factors that are not studied from his work.

Several studies identified TQM as the solution for building sustainable business in SMEs as it brings quality into products thus improving customer satisfaction as, Temtime and Solomon (2002) from their study reported TQM are considerably awarded importance by SMEs once the size of the firm increases gradually, as this growth will attract long term competitiveness and more profitability. Aich et al. (2018) indicated that TQM in SMEs can be successfully implemented by employing IT in their business operations for improving product quality and productivity. While Somerville (1994) studied the influence of five areas of barriers that challenge the implementation of TQM in the construction industry. Salaheldin (2009) among other studies identified critical success factors for TQM practices that have an affinity to enhance organization performance in SMEs, substantiating the reports of Yusof and Aspinwall (1999) that critical success factors are not focused on SMEs unlike how they were observed in large companies and have proposed significant factors for success of SMEs alongside the studies done by many authors. Rahman (2001) in his study found no significant impact of TQM on organization performance and the effect is independent of ISO 9000 certification, whereas Terziovski and Samson (1999) reflects that TQM would influence organizational performance depending on employee size in companies.

\section{HEALTH AND SAFETY IN TOTAL QUALITY MANAGEMENT SYSTEM}

Health and safety have become an integral part of every business, currently felt at every stage of operations both in larger firms and SMEs. In view of very limited research done on health and safety integration to quality management system in organizations, combining both the management systems are vital for sustaining businesses and consumer satisfaction in both larger firms and SMEs.

Research studies now indicate that the SMEs are gradually migrating to adopt integrated management systems as a sustainable mechanism to overcome the barriers and maintain business continuity and achieve organizational performance and sustainability (Stamou, 2003). Total quality management systems are standards that aim to achieve quality products which has significant relation with health and safety, as improving the latter was found to reduce injuries in organizations. Safety at work obviously will increase confidence among workers through management commitment and leadership, as these are characteristics for improving both safety and quality in organizations as described in Loushine et al. (2004). 
Considerable research studies are found, and literature is available on integrating safety into quality management systems as stated in Pun \& Hui (2002). Furthermore, integrating safety into TQM has shown practical results by providing distinct objectives, identity of business success, clear safety values; as they both show synergistic effects contrary to the studies done by Osborne and Zairi (1997) stating integration of safety to TQM has barriers and obstacles that impede the process, as both management systems have different approaches to a common goal. After all, safety orientation to total quality management system is a different dimension to promote continuous improvement, motivate employee involvement, which is prioritized through this approach by large firms.

\section{EFFECTIVENESS OF INTEGRATED MANAGEMENT SYSTEM}

Integrated management system (IMS) is widely gaining popularity by its application in all organizations over independent management systems which focuses on either total quality or environmental and occupational health and safety (Abad et al., 2014; Abad et al., 2016; Olaru et al., 2014). Moljevic et al. (2013) indicated that the integrated management system focuses on quality systems, environmental management systems, management systems for health and safety at work and a model for an integrated management system (management responsibility, system resources, product realization, measurement, analysis and improvement).

IMS is gaining momentum across SMEs and is seen as part of a management portfolio (Wilkinson \& Dale, 2000). Asif et al. (2011) defined integrated management system as set of interconnected processes that uses human resources, materials, information, infrastructural, and financial resources for achievement sustainability strategies (cited in Zahid and Ghazali, 2017:481). IMS is recognized for its integration of its goals, processes and resources (Zahid \& Ghazali, 2017). IMS is designed to focus on the involvement of stakeholders, and the needs of stakeholders (Rocha et al., 2007). This is supported further by Samy et al. (2015:987) stating that an IMS is as composite of interdependent processes that operate harmoniously, share the same pool of human, material, information, infrastructure and financial resources and are all aimed towards fulfillment of set goals to the satisfaction of the stakeholders. In that case, it is fair to claim that IMS is a system which provides a systematic structure, resources and procedures to plan, monitor and control any project related to quality, environment and safety (Griffith, 1999).

Based on most of the related literature reviews on IMS, it was highlighted that IMS focuses on the integration of three systems/standards (see figure 1) related to quality, environment, and health and safety (Samy et al. 2015). IMS has eight core principles that must exist for effective implementation and they are; customer focus and satisfaction, leadership commitment, employee participation, training and development, facts based decision making, continuous improvement, employee health and safety and realization of social responsibility, and sustainable development. However, recent studies have suggested to include other systems or standards such as corporate sustainability Asif et al. (2011); Rocha et al. (2007), risk management Labodova (2004) ergonomics Matias and Coelho (2002), agile manufacturing Bamber et al. (2000), corporate governance and AIDS Management (Singh, 2011). The addition of new standards/systems can be feasible with the IMS ingredients if deemed necessary as depicted in Figure. 1 a, b. 
Having an integrated system has the benefit of producing a more evolving and effective system (Simon et al., 2012; Karapetrovic \& Casadesus, 2009), which can fit easily with organizational self-assessment and benchmarking (Zeng et al., 2011). IMS implementation in organizations can lead to a diverse number of tangible and intangible benefits (see table 1) such as optimized management systems, increased competitiveness, effective resource utilization, efficient workflow (Zeng et al., 2011; Salomone, 2008), improved employee training (Santos et al., 2011), better teamwork (Simon et al., 2011), business management simplification (Low and Chin, 2003), reduction in bureaucracy (Asif et al., 2009; 2010; Simon et al., 2012; Zeng et al., 2010), competitive advantage achieved through effective allocation of responsibilities and accountability, cooperate social responsibility, and minimization of financial loss (Pun and Hui ,2002). Through the implementation of IMS, organizations can achieve economies of scale (Matias and Coelho, 2002), productivity, efficiency and organizational performance (Samy et al., 2015), and enhances organizational ability to adopt to volatile business environment and business sustainability (Bernardo et al., 2009); Labodova, 2004; Mackau, 2003); MolinaAzorin et al., 2008; Simon et al., 2012; Von Ahsen and Funck, 2001; Wilkinson and Dale, 2002; and Zeng et al., 2011).

Other empirical studies demonstrated other benefits which included organizational improvements, facilitating the process of goal setting, and action plans in alignment with the organizational goals, improving the decision making in relation to quality, environmental and health and safety issues, reducing the documentation efforts, and increase staff awareness of issues related to quality, environmental and occupational safety and reduce costs (Olaru et al. 2011, 2013; Raisiene, 2011; Bernardo et al., 2010; Patience, 2008).

IMS concepts have diverse benefits that can specifically overcome the challenges faced by SMEs through provisions of internal and external rewards. Olaru et al. (2014) in their report summarized the benefits of IMS which can stabilize SMEs in terms of profits and business development. However, though the IMS approach is increasingly adopted in larger firms, the concept is not gaining momentum in SMEs due to lack of awareness, proper guidance to implement, characteristics of SMEs. Conversely, Stamou (2013) indicated that the implementation of IMS is feasible and appropriate to SMEs due to the smaller nature of business activities, quick adaptability, decentralized work culture and easier communication, identical to Wells and Galbraith (1999). See Table 1.

Garengo and Biazzo (2013) stated in their study that IMS do always have definite advantages over quality management system as it enables firms to overcome difficulties dealing with separate management systems thus saving time, cost and resources - conforming to work reported in Zutshi and Sohal (2005). Analysis by Douglas and Glen (2000) revealed that there are varying levels of integration of management systems exercised by SMEs in UK, to achieve combined benefits from adopting either of the management systems. Fassoula and Rogerson (2003) explains five management tools for SMEs to fulfill an effective integrated management system, while authors Olaru et al. (2014) studied on identifying indicators to assess the performance of SMEs related to IMS. It was observed that $85 \%$ of the SMEs in Romania have managed to adopt integrated systems with either quality management or environmental management. Moljevic et al. (2013) summarized IMS benefits in SMEs and they were categorized as internal and external benefits (see table 2).

Different researchers worked extensively on developing models for integration of management systems for SMEs. Husband and Mandal (1999) suggested building a conceptual model using 
different dimensions for improvising the effect of quality integrated management systems. Stamou (2013) in his report mentioned facilitating factors for SMEs to adopt integrated management systems and states many authors previously have identified the major drivers that improvise the business of SMEs. Hillary (1999); Welford (1994); and Winder (2000) have all mentioned stakeholders, customers, local government, local community, employees and regulators are prominent agents in compelling SMEs to adopt integrated management systems, while Griffith (2000) asserted that these enterprises are bound to demonstrate assurance of quality, environmental performance and improved health and safety for confirming to legislative compliance, on par with larger firms.

Rebelo et al. (2016) asserted from his study that integration of quality, environment and occupational health and safety brings in sustainable development in organizations confirming to ISO (2018) explains external pressures are the key reasons to implement IMS in SMEs due the nature and requirement of business. While Khanna et al. (2010) deduced that IMS provides interactions among different management systems, to accomplish common objectives, consequently reducing the time for audits as required by individual management systems. Alongside Slater (1991); Douglas and Glen (2000); Jorgensen et al. (2002) and Pojasek, (2006) all concluded that IMS is beneficial for organizations saving time on documentation, resource minimization, establishing strong relations with different elements of the individual management systems and facilitating in conducting internal and external audits, but was disproved by Bernardo et al. (2009) - as individual management systems have diversified goals and complexity in implementing with limited expertise observed in SMEs. Mackau. (2003) expresses that introducing IMS in SMEs does not fully satisfy the employee and employers expectation but rather causes significant changes, probably leading to complexity in business operation. The author also stated a lack of employee integration is more obviously observed in SMEs, those implementing IMS contrary to the studies that exist on stimulating employee acceptance during integration.

\section{CHARACTERISTICS OF SMES, IMS IMPLEMENTATION AND CHALLENGES}

In considering IMS implementation and challenges in SMEs, it's important to highlight that there are characteristics associated with SMEs which differ from large organizations which impact on IMS implementation and challenges. Assarlind and Gremyr (2014) listed the SME characteristics based on the work of Ghobadian and Gallear, (1997); and Hudson et al. (2001). SME characteristics seem to focus on structure, contact, processes and people. Table 3 provides further description of each characteristic.

In support of SME Characteristics, Garengo and Biazzo (2013:314) listed the following characteristics based on various studies that may prevent the effective implementation of IMS.

- Lack of formalized strategy, as strategy is very often not made explicit

- Entrepreneurial behavior leading to many unpredictable changes in direction and priorities: SMEs consider a high structured management system as a constraint to change

- Limited managerial capacities mainly fueled by implicit and context-specific knowledge

- Operational focus leading to limited involvement in strategic and managerial activities

- Limited capital and human resources: The staff often have no extra time for managerial and strategic activities, such as implementing a management system

- Poor understanding and therefore scarce adoption of management tools 
The implementation of integrated management systems in organizations depends on parameters such as the availability of resources; competency and expertise, nature of the organization, complexity of the business operation, processes of the organization, and type of integration (Samy et al., 2015). For effective implementation, it's essential that the challenges and difficulties must be identified in order to cope and provide solutions and alternative directions. Some of the presented challenges are difficulties in organizing an IMS (Santos et al., 2011) taking long time to achieve the integration, difficulty in changing organizational culture, training staff (Asif et al., 2009) and conflict with the various standards (Karapetrovic and Willborn, 1998; Zutshi and Sohal, 2005; Asif et al., 2009).

Zeng et al. (2007) grouped these challenges into two groups; named internal and external factors. The internal factors include organizational structure, organizational culture, human resources, and understanding and perceptions, while the external factors included technical guidance, certification bodies, stakeholders and customers and institutional environment. Taking into consideration all these challenges, Samy et al. (2015) presented the factors impacting on the effectiveness of the IMS implementation as Internal barriers (resources, people and implementation) and external barriers (economic, social, legal and cultural) as presented in Table 4.

Khanna et al. (2009) indicated that focus on stakeholders, management commitment, provision of resources, training, process control and documentation structure and continuous improvement as critical success factors for IMS implementation. While Joao et al. (2012) concluded that top management involvement, financial resources, human resources, and training as critical success factors. Moreover, commitment and leadership, planning, human and materials resources, policies, objectives and targets, information and communication, and satisfaction of internal and external stakeholders were identified as critical success factors by Rebelo et al. (2016). Furthermore, Mohammed et al. (2005, 2007) concluded that management leadership and commitment, education and training, continual improvement, performance measurement, systems and processes, resources management, and stakeholders were concluded in their study as critical success factors. These factors are supported further by (Dubinski et al., 2003; Zutshi and Sohal, 2005; Holdsworth, 2003; Karapetrovic \& Willborn, 2002; Mackau, 2003; Scipioni et al., 2001; Wilkinson \& Dale, 1999; Jackson, 1996).

Additionally, Garengo and Biazzo (2013) documented that there are five enablers that are crucial for the effective implementation of IMS and they are the commitment of the management team, external facilitators, effective communication, software solution and continuous improvements. Taking all the above into consideration, a few common factors were identified in aid of effective IMS implementation in SMEs and they are listed as follows:

1. Leadership/Management Commitment

2. Resources Management

3. Effective Communications \& Information

4. Stakeholders Focus

5. Education and Training

6. Performance Measurement

7. Systems and Processes

Based on the above literature review where it is believed that IMS has the potential to enable SMEs to become sustainable, this can be achieved through the effective implementation 
of IMS that fits with SMEs characteristics. The authors presented a model (see Figure 3) based on various components which will enable SMEs to implement IMS effectively and achieve organizational performance and sustainability.

Figure 3 reflects the first step which is referred to as INPUT. The input stage considers critical success factors of implementing IMS where SMEs management provides IMS policy statements and objectives, IMS planning and performance reviews, provides enough resources (e.g., financial, physical, technical), appointment of a project manager/facilitator to lead and manage the project with a clear vision, support the implementation through the provision of human resources, information, infrastructure and equipment, put a system in place to recognize and encourage employee involvement and empowerment, and offer education and training to have qualified and trained employees who will move the implementation forward. SMEs must also focus their attention on their internal and external customers, suppliers, local authorities, and local community. Moreover, develop performance standards, progress monitoring, measure performance, benchmark performance and implement internal and external audits. Furthermore, ensuring that SMEs have the correct systems, process, and procedures to support the implementation of IMS, and building the culture of continuous improvements in seeking better ways of performing work. Also, the input stage considers the internal and external barriers where SMEs must identify these barriers and avoid them in improving their systems and process in order to support the IMS implementation.

The second stage is the OPERATION where SMEs start implementing IMS with the focus on their characteristics and follow Plan, Do, Check, and Act (PDCA), which is the basis of continuous improvement. While SMEs are implementing the selected IMS, PDCA process will be followed as follow:

- Plan: the purpose of this stage is to identify problems and possible causes and to prioritize corrective actions through drawing information/data.

- Do: This phase involves activities designed to improve the situation. These activities include the generation of possible solutions, selection of the best of these solutions through the application of different techniques such as Impact Analysis to scrutinize, and implement a pilot project on a small scale to see the workability of the identified solution

- Check: This phase will focus on observing how effective the pilot solution has been and gather data/information and learnings from it that could improve it further. Based on the check phase, results where a possible number of areas have been identified, you may make a decision whether as to repeat the "Do" and "Check" phases, incorporating your additional improvements.

- Act: Now you implement your solution. However, the use of the PDCA Cycle doesn't necessarily stop there as it's a continuous improvement initiative, you need to loop back to the Plan Phase, and find out further areas for improvement.

The third stage is the OUTPUT where after the effective implementation, SMEs will start experiencing internal and external benefits which will lead to overall improved performance and sustainable organizational development. 


\section{DISCUSSION}

Small and medium enterprises are increasingly important to be established especially in developing and underdeveloped countries to provide opportunities for employment and livelihood for the growing population. SMEs are strategic to every country as they provide services and goods in the supply chain market including to large firms. SMEs need to adopt technology changes and innovative strategies to accelerate their business growth (Gunasekaran et al., 2011), this needs substantial resources and support from management to implement the changes which has been a challenge and a barrier to many SMEs in developing and under developed nations which have limited access to innovation.

Extensive research studies on diversified topics related to SMEs for sustaining business continuity, surviving the current global challenges with reference to consumer satisfaction and product quality, indicate implementing integrated management system in SMEs as a significant measure. Although, implementing them in organizations especially in SMEs involves many internal and external factors that determine the effectiveness and benefits thereafter. IMS should be conceptualized based on the need arising in individual SMEs with focus on issues that determine its successful implementation, rather than addressing all the elements of the management systems would cause failure of IMS in these enterprises. SMEs themselves do not have strong competitors from the analysis of literature but have inherent challenges that limit their growth and flexibility to innovate.

These enterprises, in order to deliver their potential output, must address the multiple challenges by synchronizing their operations to advancements in technology that might affect these firms in delivering quality products. Hence, SMEs have expanded their scope by emphasizing the need to incorporate total quality management system and or integrated management system as means to overcome the many barriers they face over larger firms. However, adopting integrated management systems over total quality management systems in SMEs has become a need-based approach rather than purpose-based approach to justify their resilience in a competitive market. In principle, TQM and IMS have slightly similar approaches and applicability as the latter combines quality management systems to the extent of the management element in organizations - though IMS covers a wider scope of operations in SMEs, that would benefit the management from implementing individual management systems.

Globally, industries are shifting steadily towards IMS as an improvement over quality management systems to meet competitive markets which also creates an added value, especially to SMEs. Although substantial studies have proven that IMS has significant benefits over individual management systems that are essential for SMEs, which prioritize their resources and maintain business continuity. Nevertheless, there are no distinct indicators apparently identified and developed to assess the effectiveness of IMS over independent management systema in either SMEs or larger firms. Yet, most of the research studies have only critically examined either of the management systema, therefore implying that IMS is more likely to be an effective and diversified approach for sustainable business in these enterprises. Hence, need arises to examine the determining factors that significantly represent the effectiveness of integrated management systems over total quality management, presuming the fact that organization business operations are not specifically oriented to any management system.

SMEs in pursuit of excellence, must have the business growth to meet the competition in market with larger firms and should be prepared to experience transitional changes that can enable 
them to meet the business trends. As these firms have limited networking and lesser resilience to market pressures, SMEs need to have back-end support for building relationships with multinational companies and larger firms. However, SMEs operating individually, have higher risk of coping with the global market by subsequently loosing recognition and business opportunities. To the contrary, networking with partner SMEs do exist in European countries which provides stability and sustenance during recession. Such a collaboration network among SMEs benefits individual units by adding value to their products and services from being part of a supply chain market.

On the other hand, there is compulsion for all the SMEs operating in the virtual network to follow common standards for management systems, or else it would likely lead to conflicts between individual units and their performance. Therefore, working towards implementing integrated management systems within those enterprises will collectively enhance the productivity in SMEs regionally and will strengthen their inherent business continuity.

Integrating management systems in organizations including SMEs is considered a better approach over individual management systems for a sustainable business and continued growth in the global market, yet integration does not always facilitate improvement in performance unless challenges during the integration process are addressed at early stages and reasonable measures taken by every facet of management. Hence, to fully harness the benefits of integrated management systems over quality management, integration should be practiced at earlier stages of business operation in all sectors of SMEs globally.

To achieve the objectives of IMS, management should emphasize providing training to motivate employee participation and involvement at every stage of the integration process.

From the overall analysis, individual management systems existing in practice were fully meeting requirements and the TQM model has disabilities when it comes to dealing with organizational and employee demands. Thus, integrated management systems would be a feasible method to have comprehensive and practical structure within SMEs that can sustain business continuity.

\section{CONCLUSION}

Management systems are becoming more applicable to all sorts of businesses, especially in small and medium enterprises to sustain the increasing competition in the global market over larger firms, which are more stabilized in times of economic disturbances. On the contrary, economies are directing their focusing more towards these small enterprises due to the potential they have in providing employment and promising jobs in the future which could potentially sustain many businesses and employment worldwide.

In pursuit of these SMEs it is likely that potential challenges to sustain business continuity will be encountered, in addition to maintaining compliance with regulatory framework, thus necessitating these organizations to understand the significance of incorporating IMS to their business operations. However, wide research studies and proposed models on the application of different management systems have indicated a positive influence on SME businesses that would improve their performance. Nevertheless, implementing an integrated management system is considered a more effective and feasible mechanism for SMEs to ensure sustainable business continuity. Besides, there are also some significant enablers influencing IMS implementation essentially to overcome the inherent internal and external barriers that disable 
the effectiveness of SMEs over the larger firms. In this complexity of business affordability, consumer satisfaction is very critical in deciding the success and deliverance of quality products that subsequently boosts the prospects of every organization, especially SMEs, in this scope of study.

Conversely, the benefits of IMS implementation exceed across individual management systems either in larger firms or SMEs, with characteristics differing in both types of business establishments though the operational features are similar. Furthermore, to maximize the efficient use of IMS in SMEs, a three-stage model developed in this study will typically support these enterprises to attain stability and sustenance, which appends all the elements of a management system at every stage of business operation. Despite all these findings, SMEs have the necessity to broaden their view towards collaborating with larger business partners to maintain the flow of service provision and goods in a supply chain that would provide an ideal approach to achieve sustainability and improve organization performance. Nevertheless, SMEs critically need to focus on addressing the challenges limiting their business growth and to adopt improvements in technology and innovation to meet the globalization demands.

The question remains unanswered, with all the research findings, if SMEs should remain optimistic towards a competitive global market and if they will continue as potential sources for employment in future.

\section{REFERENCES}

Abad, J. Dalmau, I. and Vilajosana, J. (2014). Taxonomic proposal for integration levels of management systems based on empirical evidence and derived corporate benefits. Journal of Cleaner Production, 78, 164-173. http://dx.doi.org/10.1016/j.jclepro.2014.04.084

Abad, J. Cabrera, H. R. and Medina, A. (2016). An analysis of the perceived difficulties arising during the process of integrating management systems. Journal of Industrial Engineering and Management, 9(3), 860-878.

Aich, S. Muduli, K. Onik, M. H. and Kim, H. C. (2018). A novel approach to identify the best practices of quality management in SMEs based on critical success factors using interpretive structural modeling (ISM). International Journal of Engineering and Technology, 7, (3.29), 130-133.

Arnold, C. (2019). The foundation for economies worldwide in small business. International federation of accountants. https://www.ifac.org/knowledge-gateway/contributingglobal-economy/discussion/foundation-economies-worldwide-small

Assarlind, M. and Gremyr, I. (2014). Critical factors for quality management initiatives in small- and medium-sized enterprises. Total Quality Management \& Business Excellence, 25 (3-4), 397-411,

Asif, M. Searcy, C. Zutshi, A. and Ahmad, N. (2011). An integrated management systems approach to corporate sustainability. European Business Review, 23, 353-367.

Asif, M. Bruijn E. J. D. Fisscher, O. A. M. Searcy, C. and Steenhuis, H. J. (2009) "Process embedded design of integrated management systems". International Journal of Quality \& Reliability Management, 26, 261-82. 
Asif, M. Fischer, O. A. M. Bruijn, E. J. de. and Pagell, M. (2010). "An examination of strategies employed for the integration of management systems". The TQM Journal, 22, 648-69.

Bamber, C.J. Hides, M.T. and Sharp, J. M. (Eds.). (2000), Integrated Management Systems: An agile manufacturing enabler, $1^{\text {st }}$ International Conference on Systems Thinking in Management, November 8-10, Geelong, Australia.

Bernardo, M. Casadesus, M. Karapetrovic, S. and Heras, I. (2009). How integrated are environmental, quality and other standardized management system. An empirical study. Journal of Cleaner production, 17, 742-750.

Bernardo, M. Casadesus, M. Karapetrovic, S. and Heras, I. (2010), Management systems: integration degrees empirical study Certificate ISO, (2011), http://infocertificare.ro/consultanta-implementare-iso-16949.html, acces at la data de 23.11.2011

Douglas, A. and Glen, D. (2000). Integrated management system in small and medium enterprises. Total Quality Management, 11(4-6), 686-690.

Dubinski, J. Gruszka, E. and Krodkiewska-Skoczylas, E. (2003). Integrating Management Systems? No Problem for Pioneering Poles! ISO Management Systems, JanuaryFebruary, 43-50.

Fassoula, E. D. and Rogerson, J. H. (2003). Management tools for SMEs. Total Quality Management \& Business Excellence, 14 (10), 1143-1158.

Garengo, P. and Biazzo, S. (2013). From ISO quality standards to an integrated management system: an implementation process in SME. Total Quality Management \& Business Excellence, 24 (3), 310-335.

Ghobadian, A. and Gallear, D.N. (1997). TQM and organization size. International Journal of Operations \& Production Management, 17(2), 121-163.

Griffith, A. (1999). Developing an integrated management system for quality, safety and environment, Construction Papers, 108, Chartered Institute of Building (CIOB), Ascot, UK.

Griffith, A. (2000). Integrated management systems: a single management system solution for project control? Engineering, Construction and Architectural Management, 7 (3), 232240.

Gunasekaran, A. Bharatendra, K. R. and Griffin, M. (2011). Resilience and competitiveness of small and medium size enterprises: an empirical research. International Journal of Production Research, 49(18), 5489-5509, doi:10.1080/00207543.2011.563831.

Hillary, R. (Ed.) (1999). Evaluation of Study Reports on the Barriers, Opportunities and Drivers for Small and Medium Sized Enterprises in the Adoption of EMS. Department of Trade and Industry Environment Directorate, UK.

Hillary, R. (Ed.) (2000). Small and medium-sized enterprises and the environment: Business Imperatives. Greenleaf Publishing, Sheffield.

Holdsworth, R. (2003). Practical applications approach to design, develop and implementation of an integrated management system. Journal of Hazardous Materials, 104, 193-205. 
Hudson, M. Smart, A. and Bourne, M. (2001). Theory and practice in SME performance measurement systems. International Journal of Operations \& Production Management, 21(8), 1096-1115.

Husband, S. and Mandal, P. (1999). A conceptual model for quality integrated management in small and medium size enterprises. International Journal of Quality and Reliability Management, 16 (7), 699-713.

International Labour Organisation. (2019). The power of small: unlocking the potential of SMEs. https://www.ilo.org/infostories/en-GB/Stories/Employment/SMEs

International Organization for Standardization. (2018). The integrated use of management system standards. https://www.iso.org/files/live/sites/isoorg/files/store/en/PUB100435_preview.pdf

Jackson, S.L. (1996). The ISO14001 implementation guide: creating an integrated management system. New York: John Wiley \& Sons Inc.

Joao, A. Paulo, S. and Gilberto, S. (Eds.) (2012). Integrated management systems - quality, environment and health and safety: motivations, benefits, difficulties and critical success factors. [Conference paper] Portuguese Society of Occupational Safety and Hygiene (SPOSHO)

Jorgensen, T. H. and Simonsen, G. (2002). Prospects of a Unified Management System. Corporate Social Responsibility and Environmental Management, 9 (2), 91-98.

Karapetrovic, S. and Willborn, W. (2002). Self-audit of process performance. International Journal of Quality \& Reliability Management, 19 (1), 24-45.

Karapetrovič, S. and Willborn, W. (1998). "Integration of quality and environmental management systems". The TQM Magazine, 10, pp. 204-213.

Karapetrovic, S. and Casadesus, M. (2009). Implementing environmental with other standardized management systems: Scope, sequence, time and integration. Journal of Cleaner Production, 17(5), 533-540.

Khanna, H.S. Laroiya, S.C. and Sharma, D. D. (2009). A survey of Indian experience on integrated management standards (IMS). International Journal for Quality Research, 3(3), 1-11.

Khanna, H.S. Laroiya, S.C. and Sharma, D. D. (2010). Integrated management system in Indian manufacturing organization: some key findings from an empirical study. Total Quality Management, 22(6), 670-686.

Labodova, A. (2004). Implementing Integrated Management Systems using a risk analysisbased approach. Journal of Cleaner Production, 12, 571- 580.

Loushine, T. W. Hoonakker, P. Carayon, P. and Smith, M. J. (2004). The relationship between safety and quality management in construction. Proceedings in Human Factors and Ergonomics Society Annual Meeting, DOI: 10.1177/154193120404801658.

Low, S.P. and Chin, Y.P. (2003). Integrating ISO 9001 and OHSAS 18001 for construction. Journal of Construction Engineering and Management, ASCE, 129(3), 338-347.

Mackau. D. (2003). SME integrated management system: a proposed experiences model. Total Quality Management, 15 (1), 43-51. 
Matias, J.C.O. and Coelho, D.A. (2002). The integration of the standards systems of quality management, environmental management and occupational health and safety management. International Journal of Production Research, 40(15), 3857-3866.

Mohammad, M. Osman, M.R. Mohd. Yusuff, R. and Ismail, N. (2005). Strategies and critical success factors for integrated management systems implementation. In M.B. Durmusoglu and C. Kahraman (Eds.), Proceedings of the 35th International Conference on Computers and Industrial Engineering, (pp. 1391-1396). Istanbul, Istanbul Technical University.

Mohammed, M. Osman, M. R. Rosnah, M. Y. and Ismail, N. (2007, August 5-9). Critical success factors for implementing integrated management system (IMS): survey and case studies results. [paper presentation]. World Engineering Congress 2007, Penang, Malaysia.

Molina Azorin, J. F. Tari, J. J. Calver-Cortes, E. and Lopez-Gamero, M. D. (2008). Quality management, environmental management and firm performance: a review of empirical studies and issues of integration. International Journal of Management Reviews, 11(2), 197-222.

Moljevic, S. Rajkovic, D. Maric, B. Medakovic, V. and Durdevic, S. (2013). Integrated systems management in small and medium enterprises. International Journal of Engineering, 11(4), 315-320.

Olaru, M. Maier, D. Maier, A. and Nicoara, D. (2013). Establishing the basis for the development of an organization by adopting the integrated management systems: comparative study of various models and concepts of integration, $2^{\text {nd }}$ World Conference on Business, Economics and Management-BEM 2013, April 25 - 28 2013, Antalya, Turkey

Olaru, M. Maier, D. Nicoara, D. and Maier, A. (Eds.) (2014). Establishing the basis for development of an organisation by adopting the integrated management system: comparative study of various models and concepts of integration, Proceedings Social and Behavioral Sciences, 109, 693-697.

Olaru, M. Pirnea, I. C. Hohan, A. and Maftei, M. (Eds.) (2014). Performance indicators used by SMEs in Romania, related to integrated management systems. Proceedings Social and Behavioural Sciences, 109, 949-953.

Olaru, M. Rizea, C. and Sava, T. (2011). Promoting the concept of social responsibility by sme's in Romania, in the context of concerns the implementation of integrated management systems, în: Editor Costache Rusu, Proceedings of „The $7^{\text {th }}$ International Conference on Management of Technological Changes" - MTC , 1-3 September 2011, Alexandroupolis, Grecia

Organisation for Economic Cooperation and Development. (2017, February 19). Small, Medium, Strong. Trends in SME Performance and Business Conditions, https://www.oecd.org/industry/small-medium-strong-trends-in-sme-performanceand-business-conditions-9789264275683-en.htm

Organisation for Economic Cooperation and Development. (2019, February 19) SME and Entrepreneurship Outlook, https://doi.org/10.1787/34907e9c-en.

Osborne, J. and Zairi, M. (1997). Total Quality Management and the Management of Health and Safety (London, Health \& Safety Executive). 
Pambreni, Y. Khatibi, A. Azam, S. M. F. and Tham, J. (2019). The influence of total quality management toward organization performance. Management Science Letters, 9, 13971406.

Patience, A. (2008), Integrated Management Systems - A qualitative study of the levels of integration of three Danish Companies [Unpublished master's thesis] Science in Engineering in Environmental management.

Pinho, J. C. (2008). TQM and performance in small medium enterprises- the mediating effect of customer orientation and innovation. International Journal of Quality \& Reliability Management, 25 (3), 256-275.

Pojasek, R.B. (2006). Is Your Integrated Management System Really Integrated? Environmental Quality Management, 16(2), 89-97.

Pun, K.F. and Hui, I.K. (2002). Integrating the safety dimension into quality management systems: a process model. Total Quality Management \& Business Excellence, 13(3), 373-391.

Rahman, S. (2001). A comparative study of TQM practice and organizational performance of SMEs with and without ISO 9000 certification. International Journal of Quality \& Reliability Management, 18 (1), 35-49.

Raišiene, A. (2011). Advantages and limitations of integrated management system: the theoretical viewpoint, Social Technologies, p. 25-36

Rebelo, M. F. Santos, G. and Silva, R. (2016). Integration of management system: towards a sustainable success and development of organizations. Journal of Cleaner Production, 127, 96-111.

Rocha, M. Searcy, C. and Karapetrovic, S. (2007). Integrating Sustainable Development into Existing Management Systems. Total Quality Management and Business Excellence, 18(1-2), 83-92. http://doi.org/10.1080/14783360601051594

Rotar, L. J. Pamic, R. K. and Bojnec, S. (2019). Contributions of small and medium enterprises to employment in the European Union countries. Economic Research, 32 (1), 32963308 .

Samy, G. M. Samy, C. P. and Ammasaiappan, M. (2015). Integrated management system for better environmental performance and sustainable development: a review. Environmental Engineering and Management Journal, 14(5), 985-1000.

Salaheldin, S I. (2009). Critical success factors for TQM implementation and their impact on performance of SMEs. International Journal of Productivity and Performance Management, 58 (2), 215-237.

Salomone, R. (2008). Integrated management systems: Experiences in Italian organizations. Journal of Cleaner Production, 16(6), 1786-1806.

Santos, G. Mendes, F. and Barbosa, J. (2011). "Certification and integration of management systems: the experience of Portuguese small and medium enterprises", Journal of Cleaner Production, 19, 1965-1974.

Scipioni, A. Arena, F. Villa, M. and Saccarola, G. (2001). Integration of management systems. Environmental Management and Health, 12 (2), 134-145. 
Simon, A. Bernardo, M. Karapetrovič, S. and Casadesús, M. (2011), "Integration of standardized environmental and quality management systems audits", Vol. 19, No.3, Journal of Cleaner Production, 2057-2065.

Simon, A. Karapetrovic, S. and Casadesús, M. (2012). "Difficulties and benefits of integrated management systems". Industrial Management \& Data Systems, 112 (5), 828846. https://doi.org/10.1108/02635571211232406

Singh, R. K. (2011). Analysing the interaction of factors for success of total quality management in SMEs. Asian Journal on Quality, 12 (1), 6-19.

Singh, S., (2011). An integrative approach to management systems and business excellence. African Journal of Business Management, (5), 1618-1629.

Slater, R. (1991). Integrated Process Management. [eBook edition]. McGraw Hill.

Sommerville, J. (1994). Multivariate barriers to total quality management within the construction industry. Total Quality Management, 5 (5), 289-298.

Stamou, T. (2003). Integrated Management Systems in Small Medium-Sized Enterprises: Theory and Practice. [Unpublished master thesis]. University of East Anglia University Plain Norwich.

Temtime, Z. T. and Solomon, G. H. (2002). Total quality management and planning behavior of SMEs in developing economies. Total Quality Management, 14 (3), 181-191. https://doi.org/10.1108/09544780210425900

Terziovski, M. and Samson, D. (1999). The link between total quality management practice and organisational performance". International Journal of Quality \& Reliability Management, 16(3), 226-237.

The World Bank. (2020). Improving SMEs access to finance and finding innovative solutions to unlock sources of capital: small and medium enterprises finance. https://www.worldbank.org/en/topic/smefinance

VonAhsen, A. and Funck, D. (2001). Integrated Management Systems — Opportunities and Risks for Corporate Environmental Protection. Corporate Environmental Strategy, 8(2), 165-176. https://doi.org/10.1016/S1066-7938(01)00089-6

Welford, R. (1994). Cases in Environmental Management and Business Strategy. Pitman Publishing, London

Wells, R.P. and Galbraith, D. (1999). Proyecto Guadalajara: Promoting Sustainable Development through the Adoption of ISO 14001 by Small and Medium-Sized Enterprises. Greener Management International, (28), 90-102.

Wilkinson, G. and Dale, B.G. (1999). Integrated management system standards: an examination of the concept and theory. Total Quality Management, 11 (2), 95-104.

Wilkinson, G. and Dale, B.G. (2000). Management system standards: the key integration issues. Proceedings of the Institute of Mechanical Engineers, 214(part 9), 771-780.

Winder, C. (2000). Integrating OHS, Environmental and Quality Management Standards. Quality Assurance: Good Practice Regulation and Law, 8(2), 105-135. 
Yang, C. C. (2018). The effectiveness analysis of the practices in five quality management stages for SMEs. Total Quality Management \& Business Excellence, https://doi.org/10.1080/14783363.2018.1456010

Yusof, S. M. and Aspinwall, E. (1999). Critical success factors for total quality management implementation in small and medium enterprises. Total Quality Management, $10(4,5)$, 803-809. https://doi.org/10.1080/0954412997839

Zahid, M. and Ghazali, Z. (2017). Corporate sustainability practices and firm's financial performance: the driving force of integrated management system. Global Business and Management Research, 9, 479-491.

Zeng, S. X. Xie, X. M. Tam, C.M. and Shen, L. Y. (2010), “An empirical examination of benefits from implementing integrated management systems (IMS)", Total Quality Management \& Business Excellence, 22, 173-86.

Zeng, S.X. Shi, J.J. and Lou, G.X. (2007). A synergetic model for implementing an integrated management system: An empirical study in China. Journal of Cleaner Production, 15(18), 1760-1767.

Zeng, S. X. Xie, X. M. Tam, C. M. and Shen, L. Y. (2011). An empirical examination of benefits from implementing integrated management systems (IMS). Total Quality Management \& Business Excellence, 22(2), 173-186. https://doi.org/10.1080/14783363.2010.530797

Zutshi, A. and Sohal, A. S. (2005). Integrated management system the experiences of three Australian organisations. Journal of Manufacturing Technology Management, 16 (2), 211-232. 
Print ISSN: 2052-6393(Print), Online ISSN: 2052-6407(Online)

Figure 1a

(Source: Samy et al., 2015: 988)

Figure 1: Showing complete IMS ingredients

Table 1: IMS Categorized Benefits

\begin{tabular}{|c|c|c|}
\hline \multirow{28}{*}{$\begin{array}{l}\text { Internal } \\
\text { Benefits }\end{array}$} & \multirow[t]{9}{*}{ Functional Benefits } & Documentation Reduction, avoidance of duplication and decreased paperwork \\
\hline & & Improved Operational Efficiency \\
\hline & & Simplified Systems and procedures \\
\hline & & $\begin{array}{l}\text { Time savings and reduction in time required for implementing the Management } \\
\text { Systems }\end{array}$ \\
\hline & & Unification of audits \\
\hline & & Unification of training \\
\hline & & Common framework for continual improvement \\
\hline & & Enhances overall organizational performance \\
\hline & & Synergy between MSS \\
\hline & \multirow[t]{3}{*}{ Financial Benefits } & Cost reductions, e.g., in management, operations, and insurance premiums. \\
\hline & & Cost savings by unification and reduction of audits \\
\hline & & Reduction in certification costs \\
\hline & \multirow[t]{11}{*}{ Organizational Benefits } & Efficient use of human resources \\
\hline & & Improves organizational global strategy \\
\hline & & Better allocation of resources \\
\hline & & Improves organizational learning and growth \\
\hline & & Effective utilization of resources \\
\hline & & Clear definition of responsibilities \\
\hline & & Improves the organizations internal processes \\
\hline & & Means to sustainable development \\
\hline & & Strategic planning \\
\hline & & Holistic view \\
\hline & & Improved interdepartmental communication \\
\hline & \multirow[t]{5}{*}{ Other Benefits } & Encourage Teamwork \\
\hline & & Better options to include new systems \\
\hline & & Increased employee Morale and understanding \\
\hline & & Cultural change (Learning organization) \\
\hline & & Improvement in quality, environmental and health and safety \\
\hline \multirow{6}{*}{$\begin{array}{l}\text { External } \\
\text { Benefits }\end{array}$} & \multirow[t]{4}{*}{ Commercial Benefits } & Enhanced customer satisfaction \\
\hline & & Satisfies the beneficiaries \\
\hline & & Improved image of company \\
\hline & & Gaining competitive advantage \\
\hline & \multirow[t]{2}{*}{ Statutory Benefits } & Prerequisite for business \\
\hline & & Improvement in quality, environmental and health and safety \\
\hline
\end{tabular}

(Source: Samy et al., 2015: 995) 
Table 2: IMS categorized benefits in SMEs

\begin{tabular}{|c|c|c|}
\hline \multirow[t]{8}{*}{$\begin{array}{l}\text { Internal } \\
\text { Benefits }\end{array}$} & \multirow[t]{3}{*}{ Organizational Benefits } & $\begin{array}{l}\text { Improvement of quality of management by down-sizing three } \\
\text { functional departments to one and reducing fuzzy management } \\
\text { boundaries between individual systems }\end{array}$ \\
\hline & & $\begin{array}{l}\text { Increase in operational efficiency by harmonizing organizational } \\
\text { structures with similar elements and sharing information across } \\
\text { traditional organizational boundaries }\end{array}$ \\
\hline & & $\begin{array}{l}\text { Avoidance of duplication between procedures of systems - } \\
\text { Streamlining paperwork and communication }\end{array}$ \\
\hline & \multirow[t]{3}{*}{ Financial Benefits } & Cost savings by the reduction of the frequency of audits \\
\hline & & $\begin{array}{l}\text { Reduction in external certification costs over single certification } \\
\text { audits }\end{array}$ \\
\hline & & Increase in profit margins \\
\hline & \multirow[t]{2}{*}{ People Benefits } & Increase in employee motivation, awareness and qualifications \\
\hline & & Creation of a better company image among employees \\
\hline \multirow{9}{*}{$\begin{array}{l}\text { External } \\
\text { Benefits }\end{array}$} & \multirow[t]{3}{*}{ Commercial Benefits } & Competitive advantage, \\
\hline & & Improvement of marketplace \\
\hline & & Gain new customers/satisfy existing ones \\
\hline & \multirow[t]{3}{*}{ Communication Benefits } & Improvement of company's image \\
\hline & & Improvement of relations with stakeholders \\
\hline & & Evidence of legal compliance \\
\hline & \multirow[t]{3}{*}{ Q/E/S Benefits } & Improvement in quality, environmental and health and safety \\
\hline & & Reduction of hazardous waste generation \\
\hline & & Reduction of equipment damage and product loss \\
\hline
\end{tabular}

(Source: Moljevic et al., 2013: 318-319)

Table 3: SME characteristics

\begin{tabular}{|c|c|c|c|}
\hline Structure & $\begin{array}{l}\text { - } \begin{array}{l}\text { Flat structure with few layers } \\
\text { of management }\end{array} \\
\text { - Large degree of influence } \\
\text { exercised by individual } \\
\text { managers } \\
\text { - Informal strategies } \\
\text { - Single sited } \\
\text { - } \quad \text { Potential for quick responses } \\
\text { to external changes } \\
\text { - } \quad \text { Unified culture } \\
\end{array}$ & People & 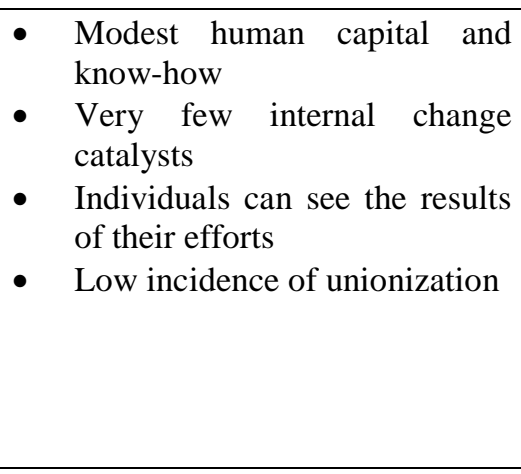 \\
\hline Contact & $\begin{array}{l}\text { - Operating in limited markets } \\
\text { with a small customer base } \\
\text { - Limited external contacts }\end{array}$ & Processes & $\begin{array}{l}\text { - } \text { Flexible processes } \\
\text { - Low degree of standardization } \\
\text { - Reactive and firefighting } \\
\text { mentality } \\
\text { - Result oriented }\end{array}$ \\
\hline
\end{tabular}

(Source: Assarlind and Gremyr, 2014: 402) 
Table 4: IMS Implementation: Internal and External Barriers

\begin{tabular}{|c|c|c|}
\hline \multicolumn{3}{|c|}{ IMS Implementation: Internal Barriers } \\
\hline \multirow[t]{6}{*}{1} & \multirow{6}{*}{$\begin{array}{l}\text { Resources and } \\
\text { Management }\end{array}$} & Insufficient financial and human resources \\
\hline & & Lack of information, expertise and insufficient training \\
\hline & & Lack of time and delays in integration \\
\hline & & Lack of management and administration support \\
\hline & & Lack of strategic planning \\
\hline & & Inadequate and methodologies and lack of specialized auditors \\
\hline \multirow[t]{5}{*}{2} & \multirow[t]{5}{*}{ People } & Lack of proper attitude and perception \\
\hline & & Lack of employees' motivation \\
\hline & & Employees rejection of new system \\
\hline & & Employees resistance due to loss of individual functions \\
\hline & & Lack of awareness \\
\hline \multirow[t]{6}{*}{3} & \multirow[t]{6}{*}{ Implementation } & Diversity of constituent MSS - different scope of individual systems \\
\hline & & Different structure of individual MMS \\
\hline & & Misunderstanding of integration concepts and lack of guidelines \\
\hline & & Reduced flexibility after integration \\
\hline & & Increase in bureaucracy due to intertwining \\
\hline & & Risk of not assigning right level of importance to each function of MSS \\
\hline \multicolumn{3}{|c|}{ IMS Implementation: External Barriers } \\
\hline \multirow[t]{2}{*}{1} & \multirow[t]{2}{*}{ Economic } & Insufficient drivers and benefits \\
\hline & & Uncertainty about value of IMS \\
\hline \multirow[t]{6}{*}{2} & \multirow[t]{6}{*}{ Social and Legal } & Lack of support schemes and guidance \\
\hline & & Lack of promotion of IMS \\
\hline & & Varying demands from different stakeholders \\
\hline & & Continually changing regulations and guidelines \\
\hline & & Unavailability of formal IMS \\
\hline & & Unavailability of common denominator \\
\hline \multirow[t]{3}{*}{3} & \multirow[t]{3}{*}{ Cultural } & Requires cultural transformation \\
\hline & & Lack of communication and teamwork \\
\hline & & Varying culture and personality clashes \\
\hline
\end{tabular}

(Source: Samy et al., 2015:996)

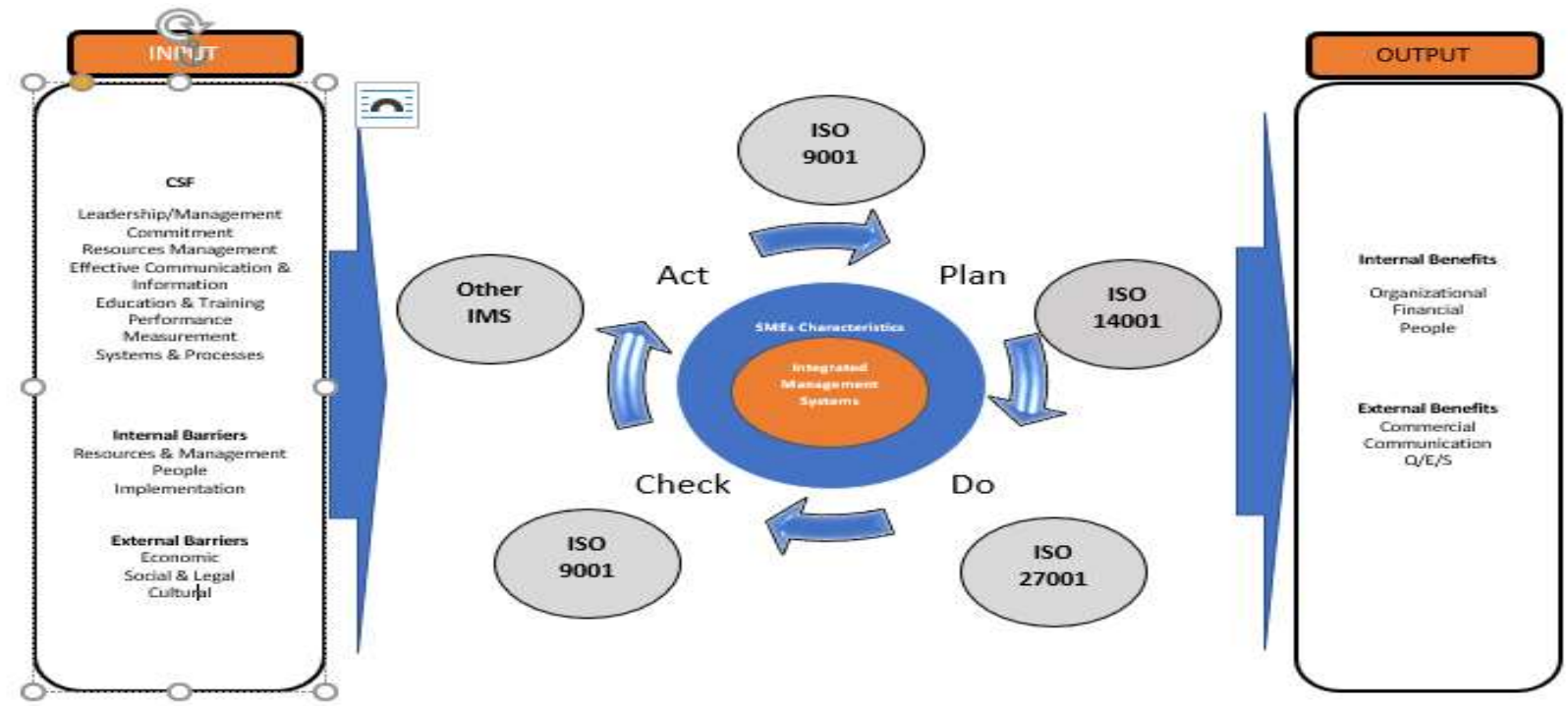

Figure 2: Proposed model by authors on IMS in SMEs 